第 2 図 同じく4週目に扣いて披裂部に見られて類 上皮細胞結節である. $(5 \times 40)$

第 3 図 B. C. G. つ小で $B_{15}$ 重感作後血行性感染 2 週目に括いて喉顽蓋基部に見られて血管周囲浸潤であ る. 遊出細胞は単球、リンパ球が主で形質細胞も諗め られる. $(5 \times 40)$

第4图 同じく6 週目において声門下腔に認められ てリンバ球，単球を主とする細胞漫潤である. $(10 \times 8)$

第 5 図 同じく 8 週目に扣いて声門下腔欴認められ て細胞浸潤である. $(10 \times 8)$

第 6 図 前記侵潤の強拡大で遊 出細胞は単 球が主 で,ツンバ球，多核白血球扣よび類上皮細胞が認めら れ，軽度の乾酪变性がある。線維母細胞の出現があ る. $(10 \times 100)$

第 7 図 B. C. G. ついで $B_{15}$ 重感作後管内性感染 2 日目に捛ける声門下腔の細胞浸潤である，上皮は膨化
している. $(5 \times 40)$

第 8 図 同じく6 週目に扣ける声門下腔の細胞浸潤 である．上皮は著しく膨化，一部脱落し多核白血球の 遊出がある。 $(5 \times 40)$

第9図 B $B_{15}$ ついで B. C.'G. 重感作後血行性感染 4 週目に扔いて披裂軟骨外側解間質に発生して単球結節 である. $(5 \times 40)$

第10図 同じく能間質内に血管を中心として発生し て単球様細胞の浸潤である。 $(5 \times 40)$

第11図 $B_{15}$ ついで B. C. G. 重感作後管内性感染 4 週目に扣ける声門下挖の単球を主とする細胞浸潤であ る. $(5 \times 40)$

第12図 同じく㬋頭蓋喉頭面に見られて䋚胞浸潤で ある。上皮は膨化している. $(5 \times 40)$

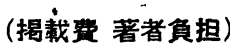

\title{
酸性色素ウラニンの経鼻粘膜吸收に及ぼす血管神経毒 および抗ヒスタミン剤の影響に関する実験的研究
}

\author{
京都府立医科大学耳鼻咽喉科学教室（主任 中村交雄 教授）
}

$$
\text { 石原雄 }
$$

目次

\begin{tabular}{|c|c|}
\hline 第1章 & 緒 \\
\hline 第2 章 & 実験方法扣よび寨験材料一般 \\
\hline 第3 章 & 実 験 成 積 \\
\hline 第 1 幯 & アドレナリン局所適用の際の吸収状態 \\
\hline 第 2 節 & $\begin{array}{l}\text { アドレナリンを注射した場合の吸収状 } \\
\text { 態 }\end{array}$ \\
\hline 第 3 節 & $\begin{array}{l}\text { アセチールヒョリンを注射して場合の } \\
\text { 四収状態 }\end{array}$ \\
\hline
\end{tabular}

\section{第1章 緒㝘}

\begin{abstract}
第4節 アトロビンを注射した場合の四収状態 第 5 節 ピロカルピンを注射した場合の吸収状 態

第6節 抗ヒスタミン剂を注射した場合の吸収 状態
\end{abstract}

第 4 章 総括ならびに考按

第 5 章 結

論

献

Copeland は種々の薬物を作用せしめて家鬼の前頭洞よりメチレンブラウを流入せしめ外舅孔よ りその流出する量を測り，それを以て鼻粘膜の薬物に対する態度を論じた。また Sternbergは鼻腔 容積の変化を描写し，三橋も同様な方法でそれを研究記載している．な抢 Sternberg は鼻粘膜血管

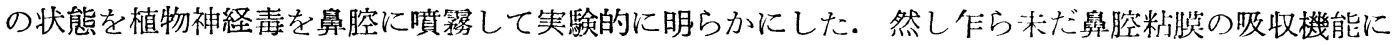
及ぼす血管神経毒の影響を実験したものは見当らない。そこで私はこの関係を究明するため本実験 を計画した。 
私は先に色素の理学的性状による悬粘膜からの吸収状態と鼻粘膜の急性炎症および血流の変化に よるそれとに関する実験的研究を行つたが，今回は酸性色素ウラニンの10\%溶液のみを用いてその 経燢粘膜吸収に諸種血管神経毒および抗ヒスタミン㨈が局所に，皮下あるいは静脈に応用された場 合如何なる影響を及ぼすかを家鬼を使用し，血清中の色素濃度を時間的に比色定量して，これを先 の無処置のもののそれとを推計学的に比較検討を加え一定の成果を得たのでここに報告する.

\section{第 2 章 実験方法ならびに実験材料一般}

1. 実験には $10 \%$ ウラニン水溶液 $0.25 \mathrm{cc} / \mathrm{kg}$ を用いた。

2. 比色にはッァイス製 Pulfrich の Stufenphotomeer を用い,フィルターは $\mathrm{L}_{3}$ を, 使用液槽は $2.5 \mathrm{~mm}$ 厚のものを用いた。

t3. 比色計の院みより血清中色素濃度を知るには先の 実験に使用したグラフ（第8図）に依つて。

4. 使用動物ならびにそれに関する注意事項, 前処 置，採血個所扣よびその方法，血清の採り方扣よびそ の比色方法等は先の実験と全く同様に行つた。

5.な扛実験の細目については次の通りである.

a) アドレナリン局所応用には 1000 倍アドレナリン 0.1ccを色素液と混合して用いた。

\section{第3章 実 験 成 績}

\section{第 1 節 アドレナリン局所適用の際の吸收状態}

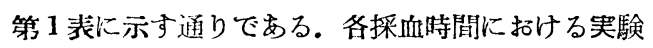
值平均の信頼度 $95 \%$ の限, 下限は 5 分； $0.07 \geqq m \supseteq$ $0.01 ， 30$ 分 $; 0.53 \geqq m \geqq 0.28 ， 60$ 分 $; 1.05 \geqq m \geqq 0.75$, 120 分; $1.11 \geq \mathrm{m} \geqq 0.66$ (単位 $\mathrm{mg} \%$ ) であつて, 最高 濃度となる時間の平上の同様信頼度に扣ける上限,下

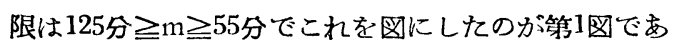
る.

第 1 図 $\times$ : 実験値平均 $\bigcirc$ : 信頼度 $95 \%$ の上限, 下限

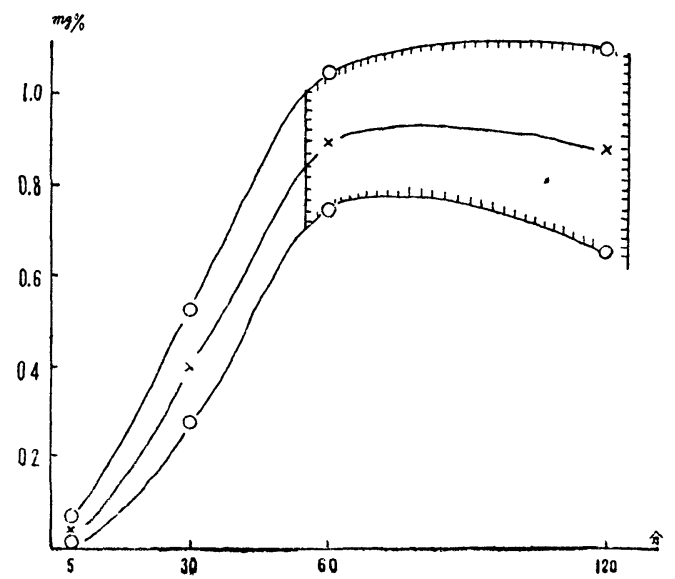

b）アドレナリン静派注射は 1090 倍アドレナリン20 $\mathrm{cc} / \mathrm{kg}$ を耳静服内に用いてて。

c) アセチールヒヨリンは $1 \mathrm{mg} / \mathrm{kg}$ を耳静服に注射し tr.

d) アトロピンは $0.4 \mathrm{mg} / \mathrm{kg}$ を胸部皮下に注射して。

e）ピロカルピンは $0.3 \mathrm{mg} / \mathrm{kg}$ を同様にして用いて。.

f）抗ヒスタミン剂はレスタミンを用い $15 \mathrm{mg} / \mathrm{kg}$ を 胸部皮下に注射した。

g） b. c. d. e. f の注射は色素液鼻腔注入後15分目に行 str.

.6 成樻の比較は先の実験の無処置のもの（第 7 図） .との間に行つた。

次に無処置のむのと平均値の時間的経過を比較する と $5 \%$ 后険率で両者の型には明らかに差が誌められ る.

\section{第 2 節 アドレナリンを注射した場合の吸收状態}

各採血洔間に托ける実駼値平均の信頼度 $95 \%$ \%上 限, 下限は 5 分 ; $0.39 \geqslant \mathrm{~m} \geqslant 0.10,30$ 分; $0.56 \geqslant \mathrm{~m} \geqslant 0.3$ 1,60 分 ; $0.85 \supseteq m \geqq 0.36,120$ 分 ; $0.78 \geqq m \supseteq 0.47$ (単 位mg\%) で, 最高濃度となる時間の平均の同様信頼 度に於ける上限, 下限は 124 分 $\geqq m \geqq 64$ 分となつてこ

第 2 図 $\times$ : 実験値平均 $\bigcirc:$ 信頼度 $95 \%$ の上限, 下限

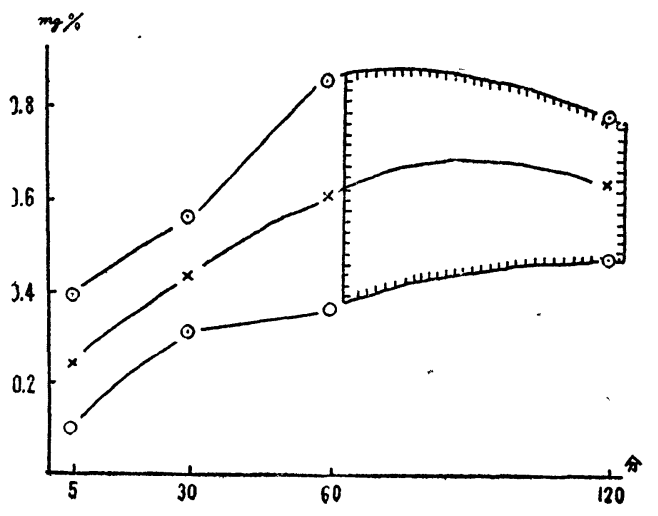


れを図にしたのが第 2 図である.

次に無処置のあの（第 7 表）と平均値の時間的経過 を比較すると $5 \%$ の佔険率で両者の型の間には明らか に差が䖵められる。

第 3 節 アセチールヒヨリンを注射した

\section{場合の吸收状態}

各採血時間に抢ける実験值 平均の信頼度 $95 \%$ の上 限, 下限は 5 分； $0.27 \geqq \mathrm{~m} \geqq 0.19,30$ 分； $1.43 \geqq \mathrm{~m} \geqq$ $0.85 ， 60$ 分； $1.42 \geqq m \geqq 1.13 ， 120$ 分； $1.39 \geqq m \geqq 0.94$ (単位 $\mathrm{mg} \%$ ) で最高濃度に上達する時間の平均の同 様信頼度に扣ける上限下限は 104 分 $\geqq \mathrm{m} \geqq 42$ 分で，こ れを図示すると第 3 図の如くである。

第 3 図 $\times$ : 実験値平均 $\bigcirc:$ 信頼度 $95 \%$ の上限, 下限

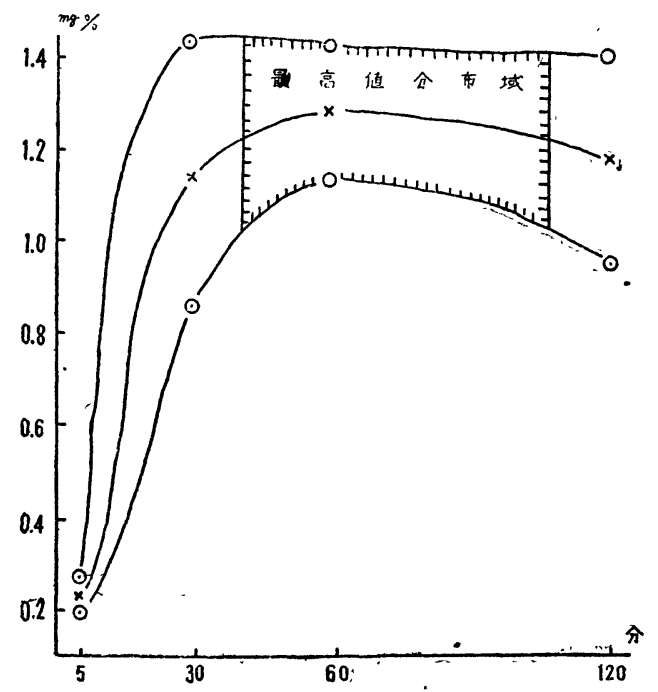

次に無処置の6の（第 7 表）之平均值の時間的経過 を比較すると $5 \%$ 伦険率で雨者の型の間には明らか に差があると言い得る。

\section{第 4 節 アトロピンを注射した時の吸收状態}

各採血時間に扣ける実験値 平均の信頼度 $95 \%$ の上 限, 下限は 5 分； $0.28 \geqq \mathrm{~m} \geqq 0.21 ， 30$ 分; $0.64 \geqq \mathrm{~m} \geqq$ $0.42 ， 60$ 分； $0.85 \geqq m \geqq 0.46 ， 120$ 分； $0.76 \geqq m \geqq 0.49$ (単位 $\mathrm{mg} \%$ ) で, 最高濃 度となる時間の平均値の上 限，下限は同様信頼度に扣いて 80 分 $\geqq \mathrm{m} \geqq 40$ 分であ

る.これらの関係を図示すると第4図である。

次に無処置のるの (第 7 表) と平均値の時聞的経過 を比較すると $5 \%$ の伦険率で両者の型の間には明らか に差があると言い得る。
第 4 図 $\times$ : 実験值平均 $\bigcirc:$ 信頼度 $95 \%$ の上限,下限

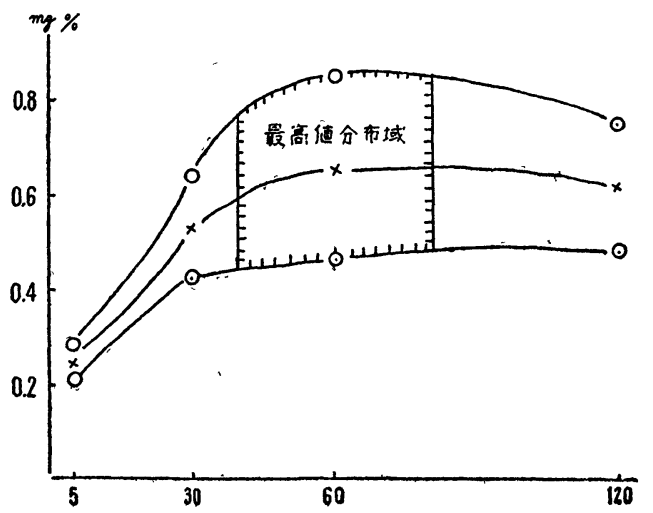

第 5 節 ピロカルピンを注射した場合の吸收状態

各採血時間に扣ける実験值平均の信頼度 $95 \%$ の上 限，下限は 5 分； $0.23 \geqq m \geqq 0.19 ， 30$ 分； $0.92 \geqq m \geqq$

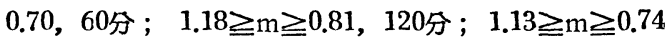
(単位mg\%) で，最高澱度に達する時間の平均値の

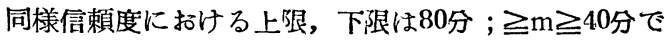
ある.これらの関係を図示すると第 5 図である. 次に無処置のちのと平均值の時間的経過を比較して みると $5 \%$ \%伦険率で雨者の型の間には明らかに差が 諗められる。

第 5 図 $\times$ : 実験値平均. $\bigcirc$ : 信頼度 $95 \%$ の上限, 下限

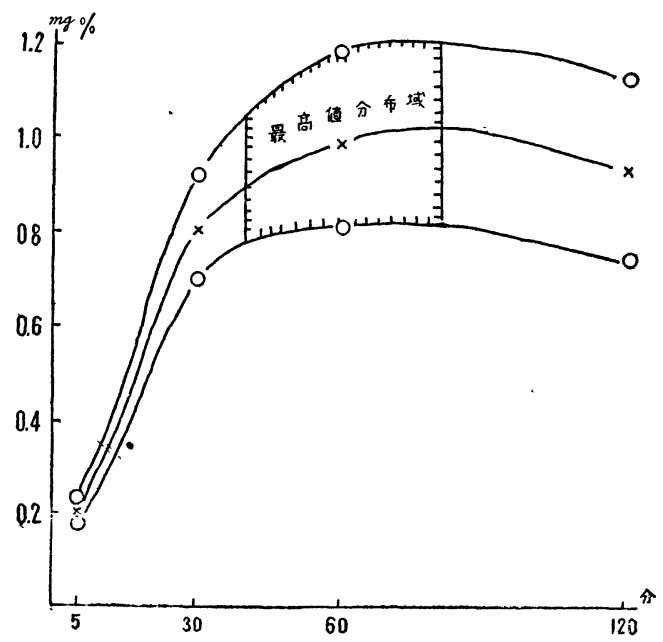

第 6 節 抗ヒスタミン剂を注射した場合の 吸收状態

各採血時間に扣ける实駼值平上の信賴度 $95 \%$ の上 限，下限は 5 分； $0.27 \geqq m \geqq 0.17 ， 30$ 分； $0.71 \geqq m \geqq$ 
$0.14,60$ 分 $; 0.70 \geqq \mathrm{~m} \geqq 0.43,120$ 分 $; 0.72 \geqq \mathrm{~m} \geqq 0.42$ (単位 $\mathrm{mg}$ ) で, 最高漂度に達する時間の平均の上限, 下泿は同様信頼度に扔いて107分 $\geqq \mathrm{m} \geqq 25$ 分となる。

次に無処置のわのと平均值の時間的経過を比較して みると両者の型の間には差があると㒛められる。

第 6 図 $\times$ : 実験値平均 $\bigcirc:$ 信頼度 $95 \%$ の上限,下限

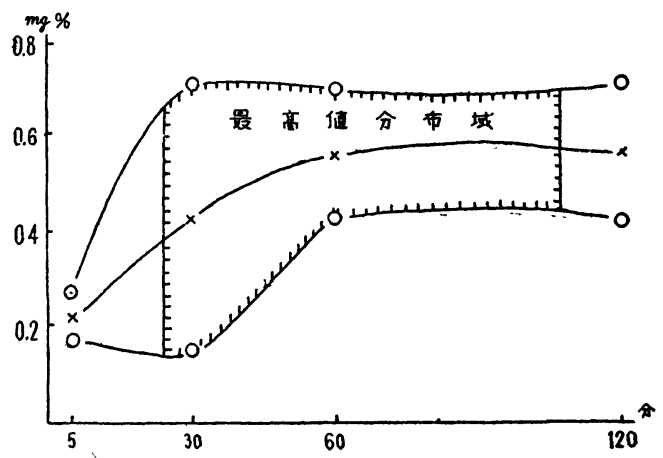

第 7 図 $\times$ : 実験値平均 $\bigcirc:$ 信頼度 $95 \%$ の上限, 下限

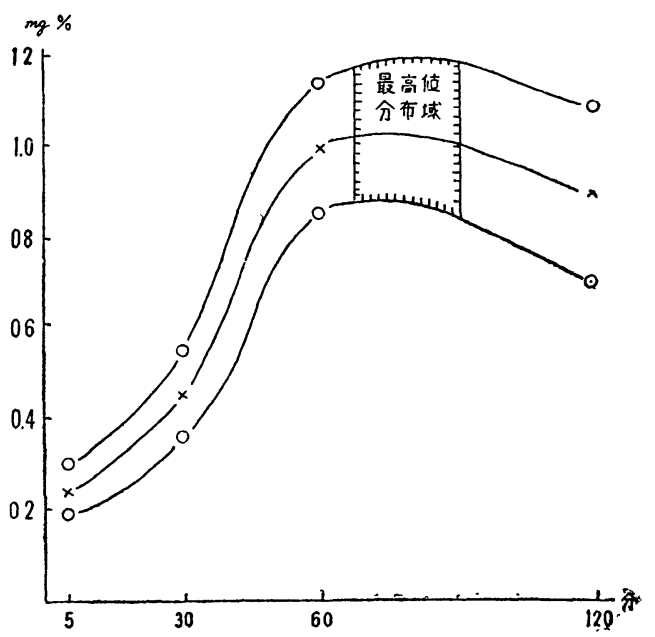

\section{第4革 総括ならびに考按}

アドレナリン局所適用 アドレナリンを鼻粘膜に滴下すると，粘膜は荅白となるとともに減張す ることは日常我々が臨床上経験していることである．この現象は Sternberg の言つた言く蒼白は皮 下毛細管網の収縮により，減張は腫脹体の萎縮によるものである，かくしてアドレナリンによつて 起るこれら細小血管の収緱は結果として色素の吸収を崌らせることは，木内が色素粒子が血管壁を 透過する場合血管の搪張，収縮が最も大なる影響を与えると述べていることによつても領かれる． 然し粘膜に鋫布されたアドレナリンは間もなく吸収されて終い皮下毛細管網や腫脹体は元の状態に かえつてゆく，その結果色素の吸収は無処置のものと大きな差がなくなる，そのうえ反射的に充血， 腫張状態を来し無処置のものの吸収より以上になるということも現われてくる.

アドレナリン静脈注射 色素の鼻腔注入後15分経つてアドレナリンを耳静脈に注射すると，やは り局所に用いた時と同様の変化が鼻粘膜に起つ 第 8 図 ていることは笑験成績より見れば明らかであ る。その間本色素の排泄器官である肝, 腎の血 管はどうなつているかというと, Schmidt の㿤 鈳によれば家鬼の肝血管は本薬物に対して不感 性であり，腎血管は収縮するがすぐ反射的に抔 張すると記載され，国岡によると肝色素排泄機 能は本剤注射直後に打いて一眭的に渋滞する が，30分後に括いては著明に九進し，4 時間後 には旧に復すると述べている．他方鼻粘膜の状 態はどうかと言うと，King 等がエフェドリン について実験を行い。犬に打いては注射後 2 分 で鼻腔容積は広くなり，血压は20分で常にかえ るが鼻粘膜の反応は 1 時間も保たれているが，

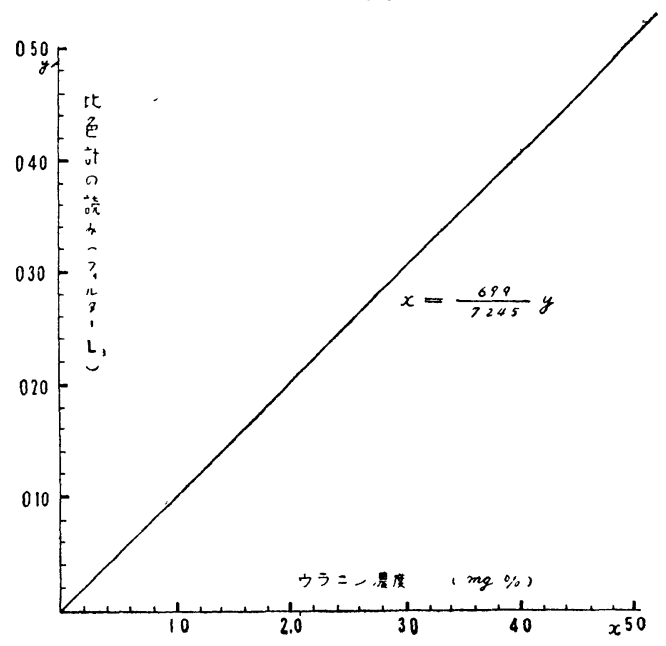


アドレナリンはその時間が比較的短かいと言つているように家鬼においても割合長く収縮の状態に あると考えられる．以上のように約 1 時間程の鼻腫張体の収縮等による色素吸収の低下，30分以後 における肝，腎の血管拉張による色素排泄作用の反射的立進によりこの実験成績は説明し得るもの と考える。な沶局所にアドレナリンを用いた時より静脈注射した時の方が色素吸収抑制作用は強く かつ長い.

アセチールヒヨリン靜胍注射 アセチールヒョリンを静脈队に注射した結果は著明な血清中色素 濃度の増加を認める，果してこの増加は鼻粘膜よりの吸収の増加のみによつて起つたものであろう か，八田は本阂は末梢血管を抁張するといい，玉尾は血管㹡張神経の末 梢に作用するものの様であ ると述べている所に依れば鼻粘膜においても毛細血管の㹡張が起つて色素の吸収が増加していると

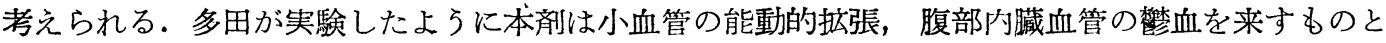

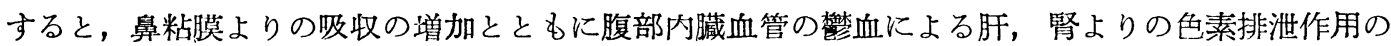
低下とが相まつてこの様な結果が現われたものと考古のが妥当である.

アトロピン皮下注射 アトロピンは副交感神経の末梢を麻瘏せしめる薬物であることは今更いう までもないが，本剤を皮下注射しだ場合どんな機転で無処置のものの血清中濃 度平均との間にこの ような時間的経過の差が現われたのであろうか。色素吸収の低下か色素排泄の増加かあるいはそれ ら両方の同時作用であるかによるに違いない，末梢血管について松島は浱度が高いと収縮すると し，下井は副交感神経の末梢に作用するがそれはピロカルピンよりも強く結合するのでその作用む 強いとしている．色素の排泄について志田は尿分泌に変化がないとし，久野は家鬼の腎血管を常に 而も比較的長く拹張すると述べ，藤森は大量では腎血管が㹡張するとしている。これらより腎の色 素排泄作用は增すことはあつても減ることはないと考兄られる．次に肝の色素排泄作用についての 影響は成山は遮延するとし，国岡は皮下に注射した場合30分および 1 時間半に著明の機能減退を来 しこれらの中間である 1 時間および 2 時間以後は正常の状態に復せんとする傾向にあり，3時間で 正常に近ずくと記述している。いずれにせよ肝の色素排泄作用は減退に傾くと考号られる，以上肝 および腎の出素排泄作用の変化からみてこの血清中色素濃度の減少は吸収量の低下なくしては説明 し得ない所で，下井が実験的に証明したように副交感神経末梢に対する 綜合力はピロカルピンより も強く，この濃度では松島の言う如く鱟粘膜血管に対しても収縮的に作用するのではないかと考え られる．上坂がいつているように家鬼鼻粘膜では副交感神経血管㹡張性の作用の方が交感神経の作 用より強いのでその作用が鼻粘膜血管においては特に強く現われているものと考えられ，兔に角吸 収量の低下なくしてはこの実験成績は説明し得ない。

ピロカルピン皮下注射 この場合の色素排泄状態はどうかと言うと腎では久野は血管の一過性の 脑張があると言い，藤森は大量は収縮性に働くと述べている所から腎の色素排泄作用は減退に傾く と見なければならぬ．又肝について成山は色素排泄時間が短縮すると述べているが，国岡の実験で は30分後は一時減退, 1 時間後克進, 1 時間半後再び淡漁してそれが 7 時間後迄つづくと結論して いる.そこで肝においても色素排泄作用はやや減退していると見るのが妥当であるょうに思える。 吸収の面では，田中は末梢血管は㹡張されるとしていることより；やはり䐴粘膜血管も㹡張され， 色素の吸収は增大していると考えなければ現われた差の説明がつかない。

抗ヒスタミン剂皮下注射 扰ヒスタミン剤注射による影響はアセチールヒョリン注射の場合と対 蹠的であつて，終始血清中色素浱度は低く保たれている。ここに拈いてるまた色素排泄量の增加か あるいは吸収量の減少かということが問題になつてくる，吸収の面に関しては，坂本，萩原は本剤 に毛細血管透過低下作用がありとし，その非特簧性の毛細血管 透過低下作用には毛細血管収縮作用 
も加わつていると考えてよいと記していることより，鼻粘膜よりの吸収もその為に可成りの低下が あると推察される。排泄の面については本剤の肝および腎に対する影響を記載したものを未だ見な いが，本剂が迷走神経に対して麻痺的に作用し，毛細血管透過性を低下せしめること等よりやはり 排泄作用が低下しているのではないかと考它られるのではないかと思う。

\title{
第5章 結
}

実験的に家鬼を用い，その固有鼻腔に10\%ウランン水溶液を注入し, 経 鼻粘膜吸収状態に及ぼす 血管神経毒ならびに抗ヒスタミン剤の影響を検べ次の結論を得た。

1.アゲレナリンは吸収を低下せしめる.

2・アセチーレ゙ヒョンは吸収を增加せしめる。

3. アトロピンは吸収を低下せしめる.

4. ピロカルピンは吸収を増加せしめる.

5. 抗ヒスタミン剤は吸収を低下せしめる.

擱筆に臨み終始御懇篤な御指導, 御校閲を睗わつて恩師中村教授に満腔の謝意を捧げる。

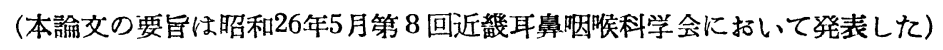

\section{慢性中耳炎より分離こたコリネバクテリウムの各種藥劑 に対する試驗管內抵抗性について}

\begin{abstract}
北海道大学医学部耳鼻栶喉科学教室（主任 猿渡二郎 教授） 北海道大学医学部細菌学教室 (主任山田守英教授)
\end{abstract}

中 畑 成 紀

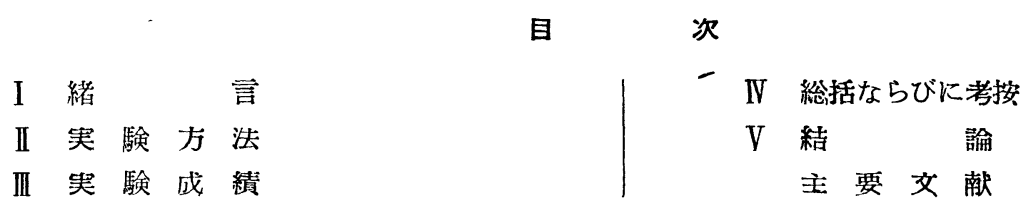

\section{I 緒言}

慢性什耳炎の耳漏には各種の細菌が証明されるが，このうちでコリネバクテリウム（以下 Cor 菌 と略す）はグラム除性の桿菌とともに治癒に重大な障害を及ぼしている事は，一般の認めるところ である。しかし個々の Cor 菌の薬阂に対する抵抗性については，未だあきらかにされていない。よ つて著者は慢性中耳炎患者から分離した各々の Cor 菌, グラム陰性の悍菌, 黄色葡萄状菌等の各種 化学療法剤に対する抵抗性を検索したのでここに報告する次第である.

\section{II 実 験方法}

此処に揭げる各種細菌の菌株はすべて慢性小耳炎の 耳漏から分離し，その純粋培養を冷藏庫 $\left(4^{\ulcorner} \mathrm{C}\right)$ に保 存しつ>あるものである.
先ずこれらの菌株の新鮮培養を作り，これを階段的 灌度に薬物を加えた培地に植えて抵抗性をしらべた。 Cor菌は先ずレフレル血清培地に植え，37`C 24 時間 